Article

\title{
Evapotranspiration and Its Partitioning in Alpine Meadow of Three-River Source Region on the Qinghai-Tibetan Plateau
}

\author{
Lifeng Zhang ${ }^{1}$, Zhiguang Chen ${ }^{1}$, Xiang Zhang ${ }^{2}$, Liang Zhao ${ }^{3}$, $\mathrm{Qi} \mathrm{Li}^{3}{ }^{\circledR}$, Dongdong Chen ${ }^{3}$, Yanhong Tang ${ }^{4}$ \\ and Song $\mathrm{Gu}{ }^{1, *}$ \\ 1 College of Life Sciences, NanKai University, 94 Weijin Road, Tianjin 300071, China; \\ 1120170360@mail.nankai.edu.cn (L.Z.); ecomaxchen@gmail.com (Z.C.) \\ 2 Institute of Life Sciences and Technology, Central South University of Forestry and Technology, \\ 498 Shaoshannan Road, Changsha 410004, China; t20192478@csuft.edu.cn \\ 3 Northwest Institute of Plateau Biology, Chinese Academy of Sciences, 23 Xinning Road, Xining 810008, China; \\ lzhao@nwipb.cas.cn (L.Z.); liqi@nwipb.cas.cn (Q.L.); chendd@nwipb.cas.cn (D.C.) \\ 4 College of Urban and Environmental Sciences, Peking University, 5 Yiheyuan Road, Beijing 100781, China; \\ tangyh@pku.edu.cn \\ * Correspondence: songgu@nankai.edu.cn
}

Citation: Zhang, L.; Chen, Z.; Zhang, X.; Zhao, L.; Li, Q.; Chen, D.; Tang, Y.; $\mathrm{Gu}, \mathrm{S}$. Evapotranspiration and Its Partitioning in Alpine Meadow of Three-River Source Region on the Qinghai-Tibetan Plateau. Water 2021, 13, 2061. https://doi.org/10.3390/ w13152061

Academic Editor: Renato Morbidelli

Received: 7 July 2021

Accepted: 26 July 2021

Published: 29 July 2021

Publisher's Note: MDPI stays neutral with regard to jurisdictional claims in published maps and institutional affiliations.

Copyright: (c) 2021 by the authors. Licensee MDPI, Basel, Switzerland. This article is an open access article distributed under the terms and conditions of the Creative Commons Attribution (CC BY) license (https:// creativecommons.org/licenses/by/ $4.0 /)$.

\begin{abstract}
The Qinghai-Tibetan Plateau (QTP) is generally considered to be the water source region for its surrounding lowlands. However, there have only been a few studies that have focused on quantifying alpine meadow evapotranspiration $(E T)$ and its partitioning, which are important components of water balance. This paper used the Shuttleworth-Wallace (S-W) model to quantify soil evaporation $(E)$ and plant transpiration $(T)$ in a degraded alpine meadow $\left(34^{\circ} 24^{\prime} \mathrm{N}, 100^{\circ} 24^{\prime} \mathrm{E}\right.$, $3963 \mathrm{~m}$ a.s.l) located at the QTP from September 2006 to December 2008. The results showed that the annual $E T$ estimated by the S-W model $\left(E T_{S W}\right)$ was $511.5 \mathrm{~mm}$ (2007) and $499.8 \mathrm{~mm}$ (2008), while $E$ estimated by the model ( $\left.E_{S W}\right)$ was $306.0 \mathrm{~mm}$ and $281.7 \mathrm{~mm}$ for 2007 and 2008, respectively, which was $49 \%$ and $29 \%$ higher than plant transpiration $\left(T_{S W}\right)$. Model analysis showed that $E T$, $E$, and $T$ were mainly dominated by net radiation $\left(R_{n}\right)$, while leaf area index $(L A I)$ and soil water content at a $5 \mathrm{~cm}$ depth $\left(S W C_{5 \mathrm{~cm}}\right)$ were the most important factors influencing $E T$ partitioning. The study results suggest that meadow degradation may increase water loss through increasing $E$, and reduce the water conservation capability of the alpine meadow ecosystem.
\end{abstract}

Keywords: evapotranspiration partitioning; soil evaporation; leaf area index; Shuttleworth-Wallace model; eddy covariance

\section{Introduction}

Hydrological processes of terrestrial ecosystems play an important role in interactions between the different spheres of the Earth (hydrosphere, biosphere, atmosphere, and geosphere), which mainly includes precipitation, evapotranspiration (ET), surface runoff, and drainage. Among them, ET is the main component of water loss from terrestrial ecosystems to the atmosphere [1,2]. ET is controlled by many environmental and biological factors; in turn, it affects not only plant growth and development but also the microclimate of plant communities. In addition, ET plays a major role in regional and global climate change [3] because it links closely to the latent heat energy, carbon, and water cycles in terrestrial ecosystems. Therefore, there has been great interest in the study of ET to better understand the links between ET and other Earth system processes [4].

$E T$ is the combination of transpiration from vegetation $(T)$ and evaporation from the soil surface $(E)$, where ET partitioning is a subject of ongoing research due to the complexity of surface energy balance processes and measurements [5-7], and is very important in predicting the responses of ecosystem water balance to climate and vegetation coverage changes [8]. The most prevalent approach for measuring ecosystem ET is eddy 
covariance (EC), which is widely used to monitor the water and carbon fluxes of the terrestrial ecosystem [9-11]. However, EC cannot separate $E$ and $T$ from ET. Up to now, models are usually employed for partitioning ecosystem ET [12]. The first two-source model that incorporated $E$ and $T$ to partition $E T$ was proposed by Shuttleworth and Wallace (S-W model) [13], and the vegetation canopy and soil surface were respectively regarded as two independent water vapor sources to partition the ET of sparse crops (maize). Since then, the $S-W$ model has been widely applied to study terrestrial ecosystem $E T, E$, and $T$ [14-16] because of its simple and accurate consideration of hydrological processes [17].

The Qinghai-Tibetan Plateau (QTP) has an average altitude over $4000 \mathrm{~m}$ above sea level and covers about 2.5 million $\mathrm{km}^{2}$; it is representative of major alpine regions of the world $[18,19]$ and plays an important role in regional and global climate and hydrological processes $[20,21]$. The principal vegetation type of the QTP is dominated by alpine meadow, which is widely distributed on the Qinghai-Tibetan Plateau with an area of about 0.7 million $\mathrm{km}^{2}$. However, the alpine meadow may be more sensitive and vulnerable to climate changes than low-elevation grassland ecosystems due to its high elevation [21,22]. The Three-River Source Region (TRSR), as the headwaters of the Yangtze, Yellow, and Mekong Rivers, is located in the central part of the QTP and is called the "water tower of Asia" [23,24]. TRSR covers an area of about $3.95 \times 10^{5} \mathrm{~km}^{2}$, of which more than $70 \%$ of the land is covered by alpine meadows [25]. The TRSR is an important water source region in Asia and provides fresh water for more than 1.4 billion people [26]. Thus, quantitative research on $E T$ and its partitioning of the alpine meadow ecosystem in TRSR are crucial not only for the sustainability of economic growth but also for environmental security. In recent decades, however, the area of the degraded meadow has been expanding in this region under the influences of climate change and human activities (e.g., over-grazing) [11,27], and the degraded grassland area accounts for about $58 \%$ of the total usable grassland [28]. Meadow degradation will not only lead to a significant decline in ecosystem productivity and restrain the sustainable development of animal husbandry, but will also greatly change the water balance and water conservation capacity of the meadow ecosystem $[29,30]$. Previous studies have indicated that meadow degradation changed the energy partitioning and carbon flux [11,25], and some studies have pointed out that the actual evaporation increased continually in the whole TRSR [31,32] and eventually led to a decrease in soil water content [33]. However, there have only been a few studies that have focused on quantifying degraded alpine meadow ET and its partitioning and revealing their relation to environmental controls. Therefore, it is necessary to quantify the degraded meadow $E$ and $T$ and it is very important to study the influence of vegetation change on ET and ET partitioning of degraded alpine meadow in TRSR.

In this study, the S-W model was used to estimate the $E, T$, and $E T$ in a degraded meadow in the TRSR from September 2006 to December 2008, and compared the estimated $E T$ with measured data from the eddy covariance system. The main objectives of our study were to: (1) characterize the seasonal pattern and interannual variation in $E T$, and quantitatively reveal the variations of $E$ and $T$ during the growing season; (2) examine the influences of physical and biological environmental variables on ET partitioning; and (3) evaluate the accuracy of the S-W model at the alpine meadow on the QTP.

\section{Materials and Methods}

\subsection{Study Site Description}

The study was conducted in a degraded meadow $\left(34^{\circ} 24^{\prime} \mathrm{N}, 100^{\circ} 24^{\prime} \mathrm{E}, 3963 \mathrm{~m}\right.$ a.s.l) in Guoluo Prefecture in Qinghai Province, China, which is located at the Three-River Source Region (TRSR) of the Qinghai-Tibetan Plateau (QTP). The local climate is a typical plateau continental climate with long cold winters and short cool summers. Based on the data from 1995 to 2004 , the monthly mean air temperature ranges from $-12.3^{\circ} \mathrm{C}$ (January) to $10.1^{\circ} \mathrm{C}$ (July), with the annual mean temperature between $-1.4-0.7^{\circ} \mathrm{C}$; the annual precipitation ranges between 381 and $551 \mathrm{~mm}$ with the mean value of $500 \mathrm{~mm}$, of which $80 \%$ fell in the growing season from May to September; and the mean annual 
sunshine time is above $2500 \mathrm{~h}$, with the annual total solar radiation ranging from 6238 to $6299 \mathrm{MJ} \cdot \mathrm{m}^{-2}$. The degraded meadow is dominated by Aconitum pendulum, Ligularia virgaurea, Pedicularis kansuensis, Oxytropis ochrantha, Ajania tenuifolia, Polygonum sibiricum, Euphorbia fischeriana, and Morina chinensis, with a mean vegetation height of less than $5 \mathrm{~cm}$ and a maximum canopy cover of $55 \%$ during the growing season. The soil of the study site is classified as Humic Cambisols [25].

\subsection{Observation Method}

The open-path eddy covariance system was installed in a flat degraded meadow at $3 \mathrm{~m}$ above the ground, with a fetch of more than $300 \mathrm{~m}$ from all directions. A threedimensional sonic anemometer (CSAT3, CSI, Logan, UT, USA) was used to measure turbulence. Variation of water vapor density was measured with the open-path $\mathrm{CO}_{2} / \mathrm{H}_{2} \mathrm{O}$ analyzer set at $10 \mathrm{~Hz}$ (Li-7500, Li-Cor, Lincoln, NE, USA). All the instruments were mounted on an observation tower of $3 \mathrm{~m}$ above the ground. Meanwhile, a micro-meteorological system was used to measure environmental variables including wind direction and velocity (014A and 034A-L, CSI, Logan, UT, USA), net radiation (CNR-1, Kipp\&Zonen, Delft, The Netherlands), soil heat flux (HFT-3, CSI, Logan, UT, USA), air temperature and humidity (HMP45C, CSI, Logan, UT, USA), soil temperature at different depths (105T, CSI, Logan, UT, USA), precipitation (TE525MM, CSI, Logan, UT, USA), soil water content at different depths (TDR, CS615, CSI, Logan, UT, USA), and other related data. All data were recorded by using dataloggers (CR5000 and CR23X, CSI, Logan, UT, USA) at 15-min intervals. The study period was from 16 September 2006, to 31 December 2008. Data gaps were filled by linear interpolation using the preceding and following data when the gap was in the nighttime, daytime gaps were filled by the relationship between solar radiation and measured H or LE [18,34].

During the growing season, leaf area index ( $L A I)$ was determined using a leaf area meter (LI-3100, Li-Cor) about once a month, where fresh leaves were cut for five quadrats of $0.25 \mathrm{~m} \times 0.25 \mathrm{~m}$ and the averaged $L A I$ for the five quadrats was used in this study. The seasonal variations of $L A I$ in 2007 and 2008 are shown in Figure 1.

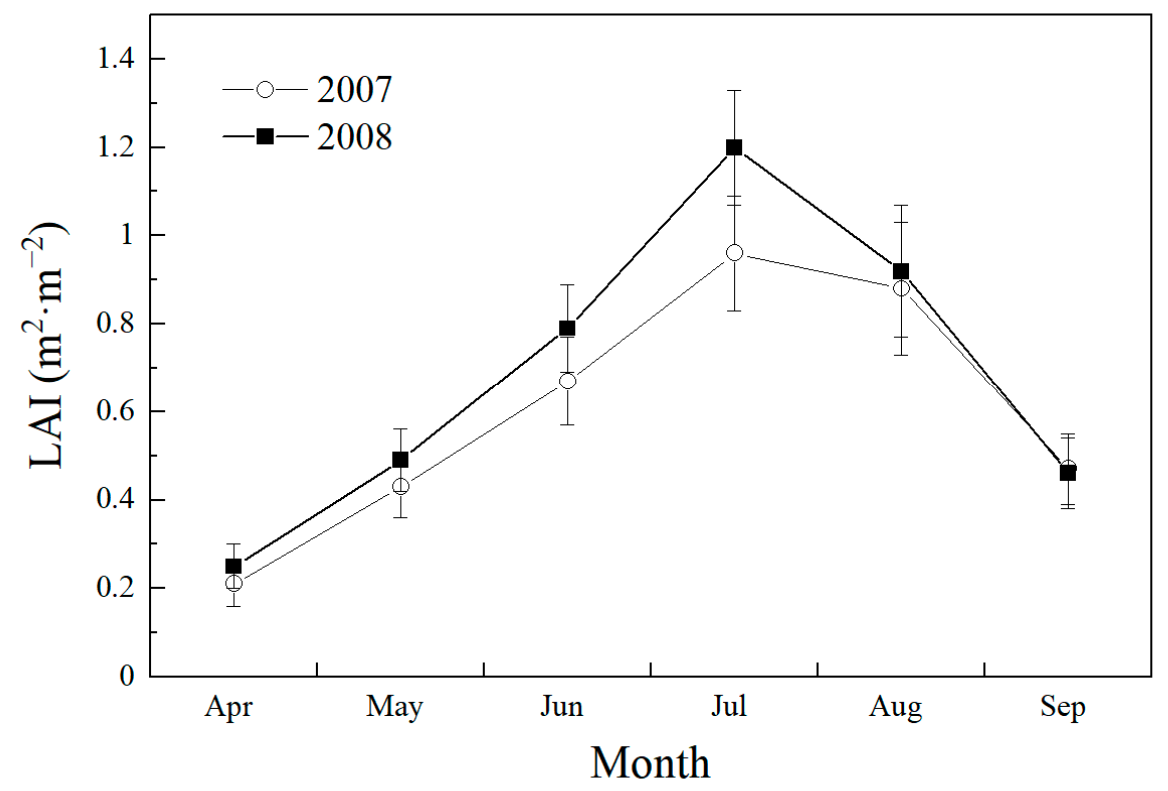

Figure 1. Variation of leaf area index $(L A I)$ during the growing season in 2007 and 2008.

\subsection{Modeling}

The S-W model was used to estimate $E$ and $T$ in this study, and the formula is as follows:

$$
E T_{s w}=E_{s w}+T_{s w}=C_{s} P M_{s}+C_{c} P M_{c}
$$


where $E T_{S W}, E_{S W}$, and $T_{S W}$ are the calculated $E T, E$, and $T$ by the S-W model and $P M_{S}$ and $P M_{c}$ are terms used to describe $E$ and $T$, respectively. $C_{S}$ and $C_{c}$ are the soil surface resistance coefficient and canopy resistance coefficient, respectively.

$P M_{s}$ and $P M_{c}$ are calculated as follows:

$$
\begin{gathered}
P M_{s}=\frac{\Delta R+\left(x C_{p} D-\Delta r_{a s}\left(R-R_{s}\right)\right) /\left(r_{a a}+r_{a s}\right)}{\Delta+\gamma\left(1+\left(r_{s s} /\left(r_{a a}+r_{a s}\right)\right)\right)} \\
P M_{c}=\frac{\Delta R+\left(x C_{p} D-\Delta r_{a c} R_{s}\right) /\left(r_{a a}+r_{a c}\right)}{\Delta+f l\left(1+\left(r_{s c} /\left(r_{a a}+r_{a c}\right)\right)\right)}
\end{gathered}
$$

where $\Delta$ is the slope of the saturation vapor pressure-temperature curve $\left(\mathrm{kPa} \cdot{ }^{\circ} \mathrm{C}^{-1}\right) ; \rho$ is the air density $\left(\mathrm{kg} \cdot \mathrm{m}^{-3}\right) ; C_{p}$ is the specific heat at constant pressure $\left(\mathrm{J} \cdot \mathrm{kg}^{-1} \cdot \mathrm{K}^{-1}\right) ; D$ is the vapor pressure deficit $(\mathrm{kPa})$; and $\gamma$ is the psychrometric constant. $R$ and $R_{S}$ represent the available energy input above the canopy and the soil surface $\left(\mathrm{W} \cdot \mathrm{m}^{-2}\right)$.

The specific equations for the S-W model can be found in $[13,35]$. We followed the methods reported by $[16,36]$ to calculate the soil surface resistance $\left(r_{s s}\right)$, and an empirical equation was found as follows:

$$
r_{s S}=13.0725\left(\frac{\theta_{s}}{\theta}\right)^{2.79457}
$$

In Equation (4), $\theta$ and $\theta_{s}$ are the soil water content $\left(\mathrm{m}^{3} \cdot \mathrm{m}^{-3}\right)$ and saturated soil water content $\left(\mathrm{m}^{3} \cdot \mathrm{m}^{-3}\right)$, respectively.

\subsection{Model Evaluation}

In this study, the statistical analysis included linear regression, root mean square error (RMSE), and mean absolute error (MSE). RMSE and MSE are calculated as follows:

$$
\begin{gathered}
\text { RMSE }=\sqrt{\frac{\sum_{i=1}^{n}\left(E_{i}-O_{i}\right)^{2}}{n}} \\
\text { MAE }=\frac{1}{n} \sum_{i=1}^{n}\left|E_{i}-O_{i}\right|
\end{gathered}
$$

where $E_{i}$ is the value estimated by the S-W model; $O_{i}$ is the observed value; and $n$ is the number of $E_{i}$ and/or $O_{i}$.

\section{Results}

\subsection{Variation of LAI and Environmental Variables}

The leaf area index $(L A I)$ in both years started to increase from May and reached its annual maximum in July, then decreased rapidly because plants began to senesce in September (Figure 1). The LAI in 2008 was higher than that in 2007, with the maximum values of $1.20(2008)$ and $0.96(2007) \mathrm{m}^{2} \cdot \mathrm{m}^{-2}$, respectively.

There were no significant differences in annual variation for each environmental variable for the study period (Figure 2), and the corresponding statistical values in the growing season (May-September) and non-growing season are listed in Table 1. The annual maximum value of daily net radiation $\left(R_{n}\right)$ appeared in June with 21.23 and $22.07 \mathrm{MJ} \cdot \mathrm{m}^{-2} \cdot \mathrm{d}^{-1}$ for 2007 and 2008, respectively, and reached the minimum value in winter. The annual $R_{n}$ in 2007 and 2008 was 2952.11 and $2939.99 \mathrm{MJ} \cdot \mathrm{m}^{-2}$, respectively, and more than $60 \%$ was received during the growing season. The annual variation of soil heat flux $(G)$ followed the same trend of $R_{n}$ with higher and lower values recorded during the growing and non-growing seasons (Figure $2 \mathrm{~b}$ ), respectively, but it fluctuated within a relatively narrow range from -3.06 to $2.27 \mathrm{MJ} \cdot \mathrm{m}^{-2} \cdot \mathrm{d}^{-1}$.

The annual variations of air temperature $\left(T_{a}\right)$ and $5 \mathrm{~cm}$ soil temperature $\left(T_{55 \mathrm{~cm}}\right)$ were strongly dependent on $R_{n}$, however, $T_{s 5 \mathrm{~cm}}$ was obviously higher than $T_{a}$ throughout the 
whole year although $T_{a}$ followed the same trend as $T_{55 \mathrm{~cm}}$ (Figure 2c). The annual mean of $T_{a}$ was $0.2{ }^{\circ} \mathrm{C}$ and $-0.6 \cdot{ }^{\circ} \mathrm{C}$, while the value of $T_{s 5 \mathrm{~cm}}$ was $3.9 \cdot{ }^{\circ} \mathrm{C}$ and $3.1 \cdot{ }^{\circ} \mathrm{C}$ for 2007 and 2008 , respectively.
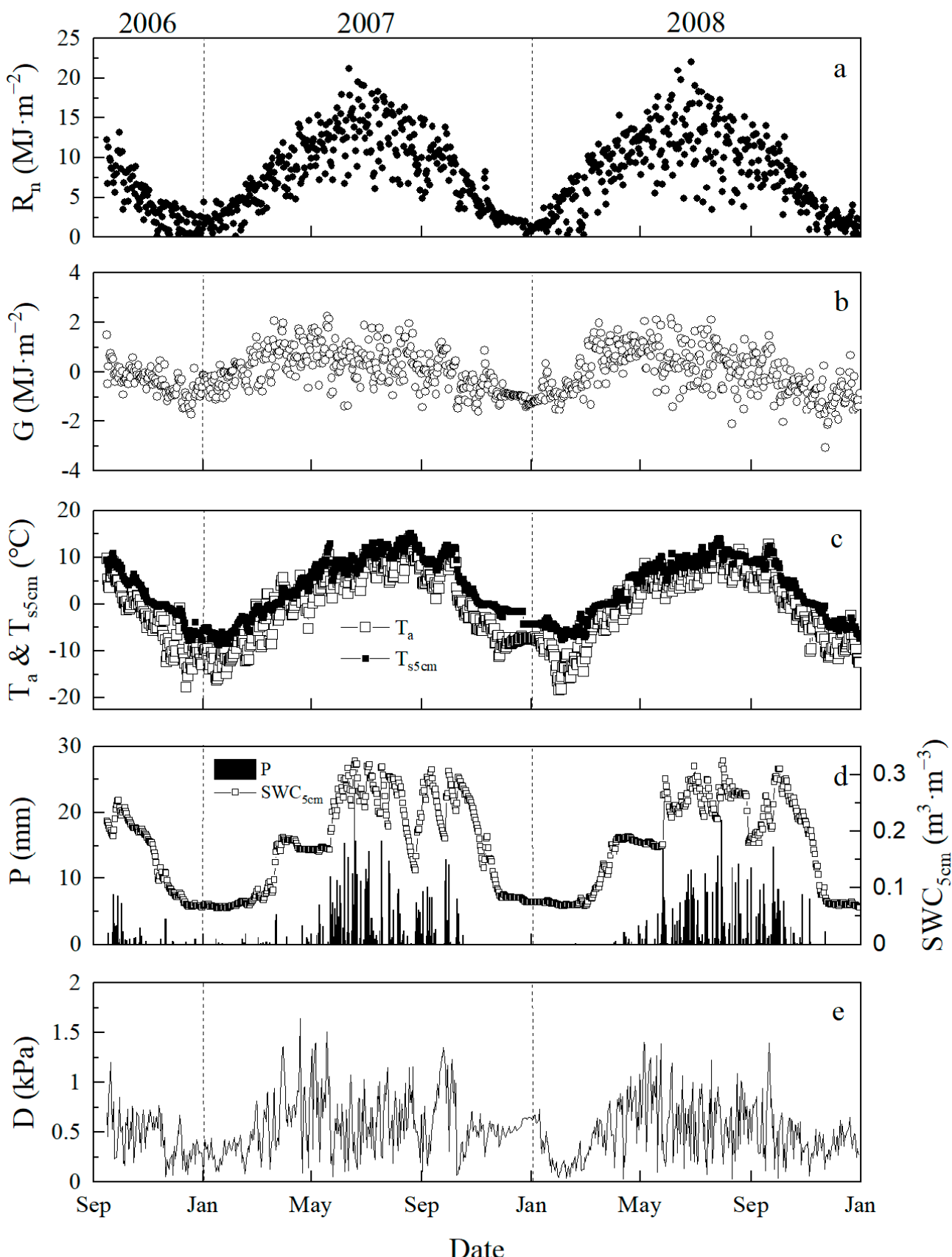

Figure 2. Annual variation of (a) net radiation $\left(R_{n}\right)$, (b) soil heat flux $(G)$, (c) air temperature $\left(T_{a}\right)$ and $5 \mathrm{~cm}$ soil temperature $\left(T_{55 \mathrm{~cm}}\right),\left(\right.$ d) precipitation $(P)$ and $5 \mathrm{~cm}$ soil water content $\left(S W C_{5 \mathrm{~cm}}\right)$, and (e) vapor pressure deficit $(D)$ in degraded alpine meadow from 2006 to 2008. 
Table 1. Comparison of environmental conditions during the growing and non-growing seasons at the study site.

\begin{tabular}{|c|c|c|c|c|c|c|c|c|}
\hline Year & Growing Phase & $\begin{array}{c}R_{n} \\
\left(\mathrm{MJ} \cdot \mathrm{m}^{-2} \cdot \mathrm{d}^{-1}\right)\end{array}$ & $\begin{array}{c}G \\
\left(\mathrm{MJ} \cdot \mathrm{m}^{-2} \cdot \mathrm{d}^{-1}\right)\end{array}$ & $T_{a}\left({ }^{\circ} \mathrm{C}\right)$ & $T_{s 5 \mathrm{~cm}}\left({ }^{\circ} \mathrm{C}\right)$ & $P(\mathrm{~mm})$ & $\begin{array}{c}S W C_{5 \mathrm{~cm}} \\
\left(\mathrm{~m}^{3} \cdot \mathrm{m}^{-3}\right)\end{array}$ & $D(\mathbf{k P a})$ \\
\hline \multirow[t]{2}{*}{2006} & 16 Sept.-31 Dec. & 4.43 & -0.38 & -3.8 & 1.1 & 56.3 & 0.15 & 0.44 \\
\hline & Annual & 8.09 & 0.11 & 0.2 & 3.9 & 493.0 & 0.18 & 0.58 \\
\hline \multirow[t]{3}{*}{2007} & Growing season & 12.24 & 0.47 & 7.1 & 10.2 & 439.7 & 0.24 & 0.67 \\
\hline & Non-growing season & 5.09 & -0.15 & -4.8 & -0.7 & 53.3 & 0.13 & 0.51 \\
\hline & Annual & 8.03 & -0.05 & -0.6 & 3.1 & 480.4 & 0.17 & 0.51 \\
\hline \multirow[t]{2}{*}{2008} & Growing season & 11.71 & 0.39 & 6.6 & 9.4 & 417.6 & 0.24 & 0.64 \\
\hline & Non-growing season & 5.39 & -0.36 & -5.7 & -1.5 & 62.8 & 0.13 & 0.41 \\
\hline
\end{tabular}

$R_{n}$, net radiation; $G$, soil heat flux; $T_{a}$, air temperature; $T_{s 5 \mathrm{~cm}}, 5 \mathrm{~cm}$ soil temperature; $S W C_{5 \mathrm{~cm}}, 5 \mathrm{~cm}$ soil water content; $D$, vapor pressure deficit.

Precipitation occurred mainly during the growing season (Figure 2d), which accounted for $89 \%$ and $87 \%$ of annual precipitation in 2007 and 2008 , respectively. The mean daily precipitation was $2.9 \mathrm{~mm} \cdot \mathrm{d}^{-1}$ and $2.7 \mathrm{~mm} \cdot \mathrm{d}^{-1}$ during the growing season in 2007 and 2008 , respectively, while it was only $0.3 \mathrm{~mm} \cdot \mathrm{d}^{-1}$ in the non-growing season for both years. The highest monthly precipitation appeared in June for 2007 and 2008, with the value of $147.5 \mathrm{~mm}$ and $101.7 \mathrm{~mm}$, respectively. There was a significant variation in $S W C_{5 \mathrm{~cm}}$ during the growing season (Figure 2d), which was strongly influenced by precipitation events and $E T$. This increased rapidly after the occurrence of rainfall and decreased due to $E$ and $T$ when no precipitation occurred. $S W C_{5 \mathrm{~cm}}$ varied with a range of $0.13-0.32$ and $0.17-0.32 \mathrm{~m}^{3} \cdot \mathrm{m}^{-3}$ during the growing season in 2007 and 2008 with a higher value in June to August, respectively.

Vapor pressure deficit $(D)$ (calculated between 11:30 and 15:30 Beijing Standard Time (BST)) varied within a narrow range between from 0.03 to $1.64 \mathrm{kPa}$ for the study period (Figure 2e). No significant difference was noted for the annual variation trend of $D$ between 2007 and 2008, and overall $D$ exhibited a relatively higher value in May and lower value in January.

\subsection{Annual Variation of ET}

Annual change of modeled evapotranspiration $\left(E T_{S W}\right)$ approximately followed the same trend as $R_{n}$ (Figure 3 ) and showed a large day to day variation during the growing season. $E T_{S W}$ started to increase from March and reached its highest annual value around July, and then decreased to the lowest value around January. The majority of $E T_{S W}$ occurred during the growing season, which was $409.9 \mathrm{~mm}$ and $395.3 \mathrm{~mm}$ in 2007 and 2008, accounting for $80 \%$ and $79 \%$ of annual $E T_{S W}$, respectively (Table 2).

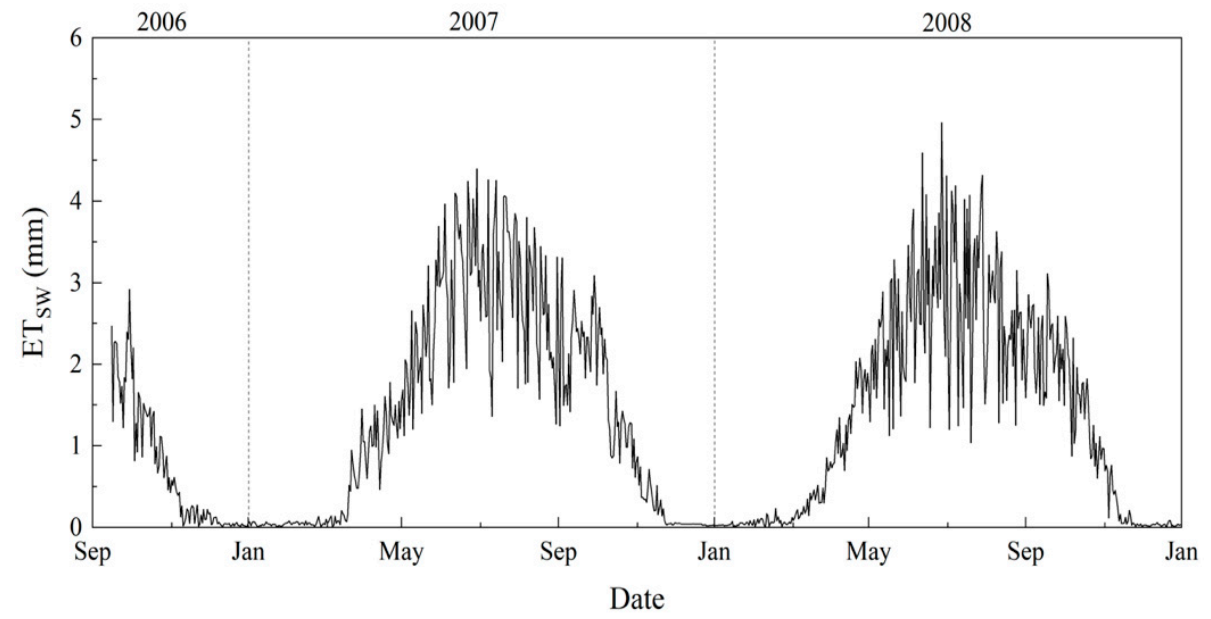

Figure 3. Annual variation of evapotranspiration estimated by the $S-W$ model $\left(E T_{S W}\right)$ in the degraded meadow for 2006-2008. 
Table 2. Evapotranspiration partitioning during the study period.

\begin{tabular}{ccccc}
\hline Year & Growing Phase & $\boldsymbol{E}_{\boldsymbol{S W}}(\mathbf{m m})$ & $\boldsymbol{T}_{\boldsymbol{S W}}(\mathbf{m m})$ & $\boldsymbol{E T}_{\boldsymbol{S W}}(\mathbf{m m})$ \\
\hline \multirow{2}{*}{2006} & 16 Sept.-31 Dec. & 51.1 & 24.2 & 75.3 \\
\multirow{2}{*}{2007} & Annual & 306.0 & 205.5 & 511.5 \\
& Growing season & 217.6 & 192.3 & 409.9 \\
& Non-growing season & 88.4 & 13.2 & 101.6 \\
\multirow{2}{*}{2008} & Annual & 281.7 & 218.1 & 499.8 \\
& Growing season & 188.1 & 207.2 & 395.3 \\
& Non-growing season & 93.6 & 10.9 & 104.5 \\
\hline
\end{tabular}

\subsection{Evapotranspiration Partitioning}

There was an obvious difference between seasonal variations in modeled evaporation $\left(E_{S W}\right)$ and transpiration $\left(T_{S W}\right)$ during the study period (Figure 4$) . E_{S W}$ increased rapidly from early March, reached its maximum value of $3.1 \mathrm{~mm}$ (2007) and $2.4 \mathrm{~mm}$ (2008) in June, then started to decrease, whereas a relatively lower value was observed in July and August of the growing season. After that, $E_{S W}$ began to increase again with a second peak appearing around October, and then decreased rapidly from late October. $T_{S W}$ in both 2007 and 2008 increased from late April when plants started to grow, with the maximum value in July and/or August when $E_{S W}$ had a relatively lower level. Then, $T_{S W}$ decreased to its minimum value in late October. The annual amount of $E_{S W}$ and $T_{S W}$ accounted for about $60 \%$ and $40 \%$ of $E T_{S W}$ in 2007 , while the values were $56 \%$ and $44 \%$ in 2008 , respectively. During the growing season, the amount of $E_{S W}$ and $T_{S W}$ in 2007 (2008) accounted for 53\% $(48 \%)$ and $47 \%$ (52\%) of $E T_{S W}$, respectively, indicating that soil evaporation was higher than plant transpiration, even though the vegetation was fully developed (for more details see Table 2).

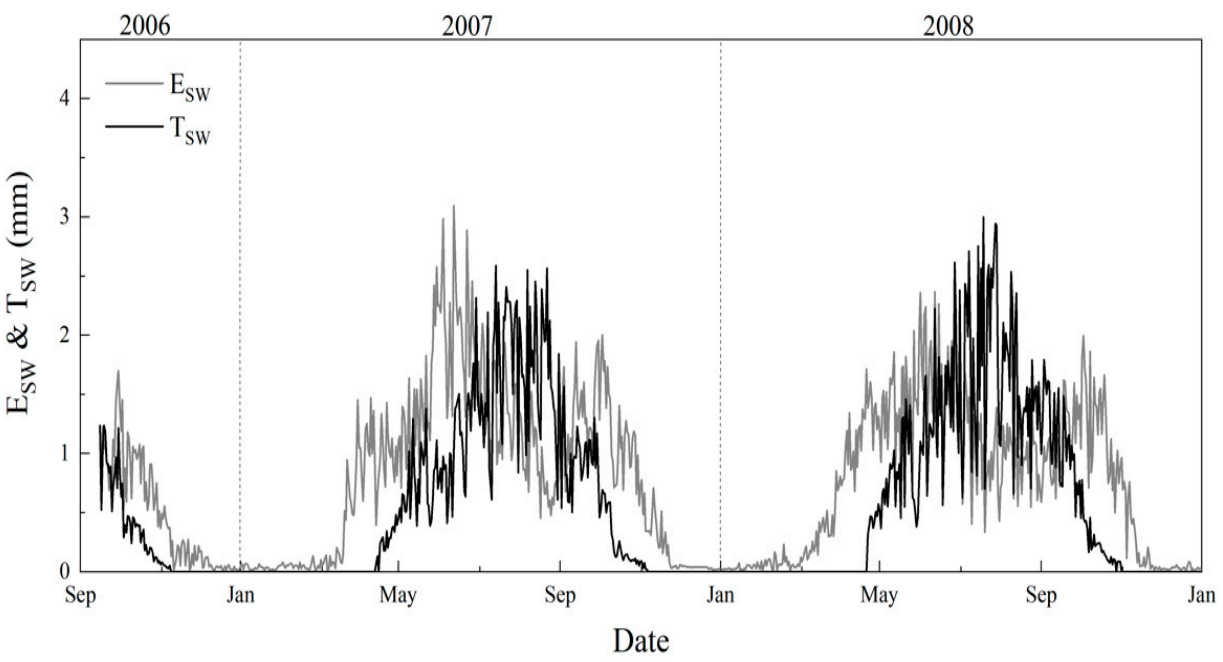

Figure 4. Annual variations in soil evaporation $\left(E_{S W}\right)$ and plant transpiration $\left(T_{S W}\right)$ estimated by the S-W model in the degraded meadow for 2006-2008.

To further explore the influence of $E_{S W}$ and $T_{S W}$ on the $E T_{S W}$, we analyzed the monthly dynamics of $E_{S W} / E T_{S W}$ of the degraded meadow throughout the study period (Figure 5). During the period from November to April of the next year, $E T_{S W}$ was accounted for by the $E_{S W}$ (i.e., $E_{S W} / E T_{S W}=1.0$ ) because the growth of plants stopped. $E_{S W} / E T_{S W}$ gradually decreased from May with the plant growth and reached its minimum value of 0.35 (in August 2007 and in July 2008), then $E_{S W} / E T_{S W}$ increased again until November. The average monthly $E_{S W} / E T_{S W}$ was 0.50 during the growing season. 


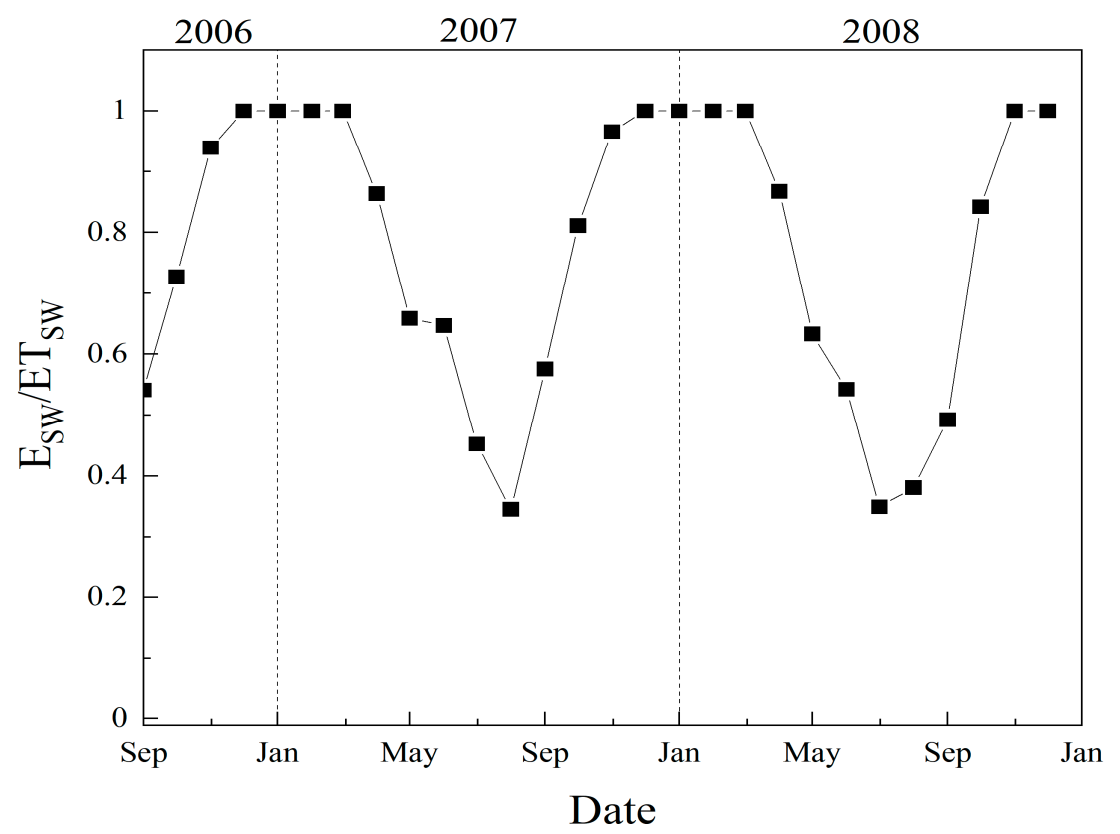

Figure 5. Seasonal dynamics of the ratio of monthly soil evaporation to monthly evapotranspiration $\left(E_{S W} / E T_{S W}\right)$ estimated from the S-W model in degraded meadow for 2006-2008.

\subsection{Diurnal Variation of ET}

Diurnal variations of $E_{S W}, T_{S W}$, and $E T_{S W}$ of clear days in January and July (used to represent winter and summer extreme conditions, respectively) for 2007 and 2008 are shown in Figure 6, where a clear day is defined as that on which the daily transmissivity was greater than 0.7 [18]. All three variables showed the same variation pattern for the two years of 2007 and 2008. In January, $E T_{S W}$ began to increase around 09:00 and peaked between 13:00 and 15:00 with the maximum average value of about $0.02 \mathrm{~mm} \cdot \mathrm{h}^{-1}$, then began to decrease and fell to nearly zero at around 19:00 for both years. In July, however, $E T_{S W}$ began to increase around 07:00 and reached the maximum at about 14:00, then decreased to about zero at 21:00. Although the $E T_{S W}$ showed a similar pattern for July and January, the maximum average value of the former with about $0.6 \mathrm{~mm} \cdot \mathrm{h}^{-1}$, which was much higher than that of the latter. In addition, it was found that daily $T_{S W}$ was higher than $E_{S W}$ in July in both 2007 and 2008 (especially in 2008). In July, daily $E_{S W}$ with the value of $1.8 \mathrm{~mm}$ in 2007 was higher than that of $1.5 \mathrm{~mm}$ in 2008, and the daily ratio of $E_{S W}$ to $T_{S W}\left(E_{S W} / T_{S W}\right)$ was 0.80 in 2007, which was higher than that of 0.58 in 2008, while the daily ratio of $E_{S W}$ to $E T_{S W}\left(E_{S W} / E T_{S W}\right)$ was 0.44 and 0.37 in 2007 and 2008, respectively. In other words, the contribution of $E_{S W}$ to $E T_{S W}$ in 2007 was higher than that in 2008 in July of the growing season. 

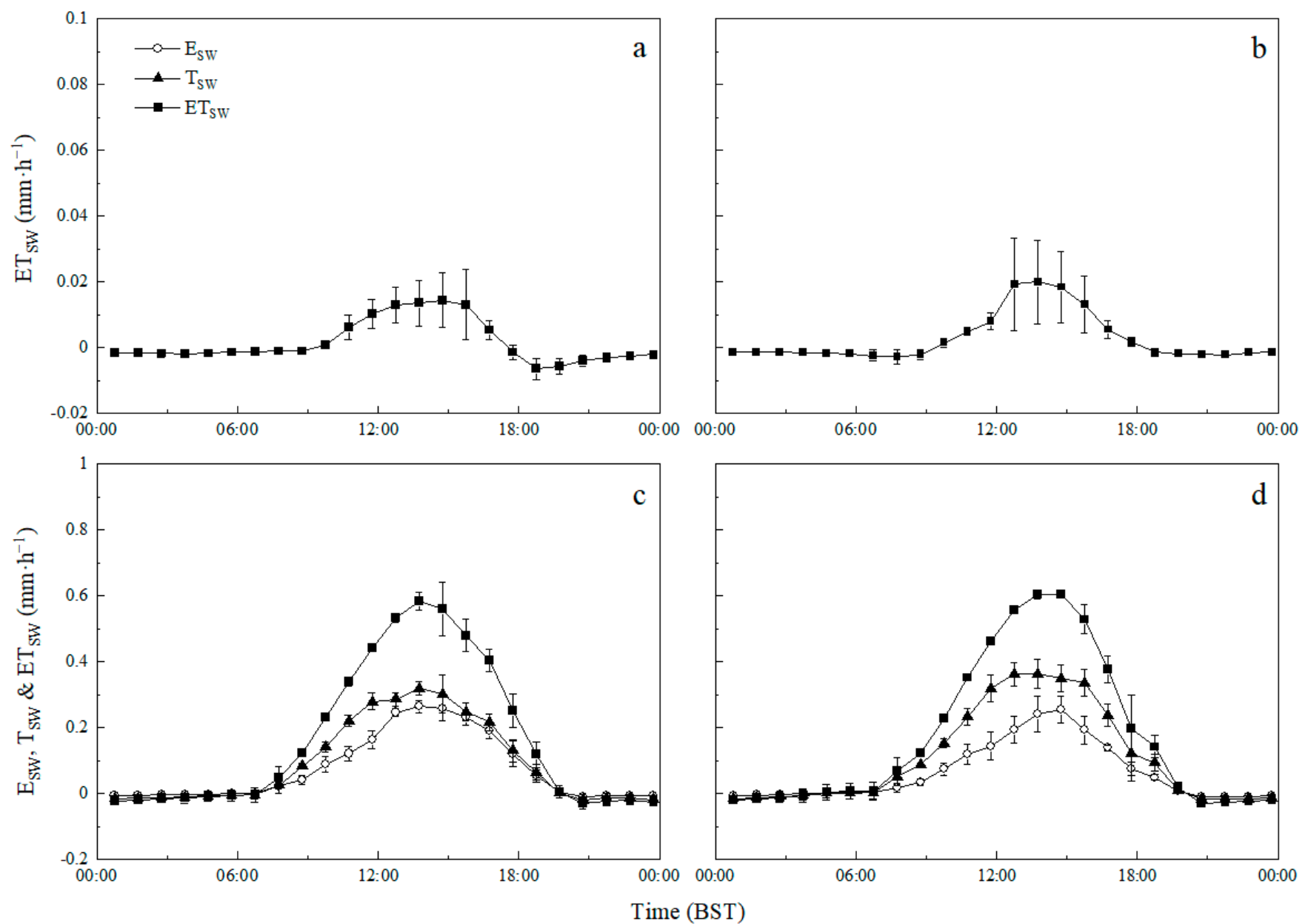

Figure 6. Diurnal variations of evaporation $\left(E_{S W}\right)$, transpiration $\left(T_{S W}\right)$, and evapotranspiration $\left(E T_{S W}\right)$ estimated by the S-W model on clear days in (a) Jan 2007, (b) Jan 2008, (c) Jul 2007, and (d) Jul 2008.

\section{Discussion}

Our simulation results indicated that $E$ accounts for a major part of $E T$ due to vegetation degradation. For environmental (biotic and abiotic) factors that may affect $E T$ and its partitioning, and for the model validation, our research showed the following results:

1. $\quad E / E T$ in our research site was more sensitive to change in LAI. E/ET decreased rapidly with the increase of $L A I$ (paragraph 1 in Section 4.1);

2. Grassland ecosystems with lower $L A I$ and/or vegetation coverage may lose more water through $E T$ (paragraph 2 in Section 4.1).

3. Net. radiation had little effect on ET partitioning, but had a great influence on $E T, E$, and $T$ (paragraph 2 in Section 4.2).

4. Air temperature had a greater effect on $T$ than on $E$ (paragraph 3 in Section 4.2).

5. Soil water content at a $5 \mathrm{~cm}$ depth affected both ET and ET partitioning in this degraded meadow, especially for the $E$ (paragraph 4 in Section 4.2).

6. Vapor pressure deficit had little effect on both $E T$ and $E T$ partitioning (paragraph 5 in Section 4.2).

7. Leaf area index is an important factor influencing ET partitioning (paragraph 6 in Section 4.2).

8. The model results had good agreement with the $E T$ observed by the eddy covariance system (paragraph 2 in Section 4.3). 


\subsection{Effects of Vegetation on Evapotranspiration Partitioning}

$E T$ is mainly dependent on vegetation, meteorological conditions, and soil water [37], and the partitioning of $E T$ into $E$ and $T$ is strongly influenced by changes in vegetation characteristics during the growing season [38,39]. Leaf area index (LAI) is often used to quantify terrestrial ecosystem ET as well as ET partitioning; an increase in leaf area will initially increase $E T$ when the soil water content is high, and this response will weaken at high $L A I[40,41]$. In this degraded meadow, the variation pattern of $E$ is quite different from that of $T$ during the growing season (Figure 4). Seasonal variation of $T$ followed the same trend of $L A I$, with the higher values recorded around August at higher $L A I$ (Figure 1), however, the highest $E$ occurred around June. The result is consistent with many literature reports $[39,42,43]$. The analysis of the relationship between $L A I$ and $E / E T$ during the growing season is illustrated in Figure 7. The E/ET data were LAI-bin averaged because this data compilation helped to reduce or offset the errors associated with the measurements [34]. The LAI gaps were linearly interpolated to daily intervals [44]. It was found that there was a significant negative correlation between E/ET and LAI for 2007 and 2008 (Figure 7) (i.e., the contribution of soil evaporation to evapotranspiration decreased linearly with the increase in $L A I$ ), which is consistent with other alpine meadow ecosystems reported by [17]. A previous study also reported a similar negative relationship in multiple ecosystems (e.g., forests, crops, wetlands, shrubs, and grasses) [45]. Several studies have reported that $E / E T$ initially decreased rapidly with an increase in $L A I$ at the low vegetative cover (low $L A I$ ), while the response of $E / E T$ to $L A I$ decreased gradually with the increasing $L A I$, and finally approached a constant value $[14,17,43,45]$. In the present study, however, the $L A I$ was very low, even in the peak growing season, with the maximum value of $1.20 \mathrm{~m}^{2} \cdot \mathrm{m}^{-2}$ (July 2008) due to the meadow degradation, therefore, $E$ /ET was more sensitive to change in $L A I$. Based on the diurnal variation of $E T$ partitioning in the peak growing season of July (Figure 6), the daily E/ET in 2007 was obviously higher than that in 2008 due to the relatively high LAI in 2008 compared with 2007. In addition, $E$ in the growing season of 2007 was higher than that of 2008 whereas the opposite result was obtained for $T$ (Table 2), and the regression line between E/ET and LAI for 2007 was above that for 2008, indicating that the contribution of $E$ to $E T$ in 2007 was higher than that in 2008, which may be due to the lower LAI for 2007 compared with 2008 that resulted in the increase in ET of this alpine meadow (Table 2).

To further investigate the relationship between vegetation and ET partitioning, we made a comparison between our results and some of the previously published studies on grassland ecosystems (Table 3). All of these studies reported a negative relationship between vegetation conditions and $E / E T$, which is consistent with our research. However, it is worth noting that worse vegetation conditions corresponded to higher ET/P (the ratio of evapotranspiration to precipitation) (Table 3). We suggest that this is due to the degradation of vegetation thus allowing more energy to reach the soil surface, which leads to increased $E$ and ET. Furthermore, Gu et al. [9] found a curve relationship between the aboveground biomass and ET at an alpine meadow ecosystem. That is, ET increased gradually with the increase in aboveground biomass at first, but decreased thereafter despite the biomass still increasing. 


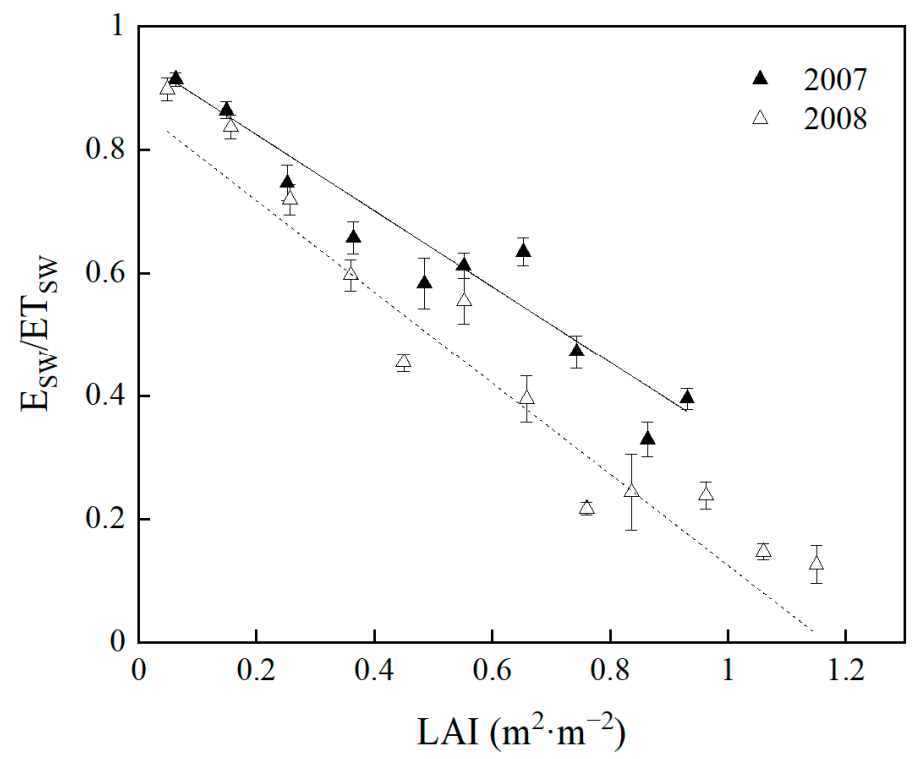

Figure 7. Relationships between leaf area index $(L A I)$ and the ratio of soil evaporation to evapotranspiration estimated by the S-W model $\left(E_{S W} / E T_{S W}\right)$ for 2007 and 2008 . The $E_{S W} / E T_{S W}$ data for 2007 and 2008 were averaged with $L A I$ bins of $0.1 \mathrm{~m}^{2} \cdot \mathrm{m}^{-2}$. Bars indicated \pm 1 standard error. The solid line represents the fitted regression for the data of 2007 , the dash line represents the fitted regression for the data of 2008. For 2007: $E_{S W} / E T_{S W}=-0.62 \times L A I+0.95, \mathrm{R}^{2}=0.96, p<0.001$; for 2008: $E_{S W} / E T_{S W}=-0.59 \times L A I+0.89, \mathrm{R}^{2}=0.96, p<0.001$.

\subsection{Effects of Environmental Factors on Evapotranspiration Partitioning}

Except for the vegetation $L A I$, solar radiation, temperature, soil moisture, and air humidity will also have an impact on the partitioning of evapotranspiration $[9,10,50,51]$. Consequently, to comprehensively understand the control of environmental factors on the balance between evaporation and transpiration, net radiation $\left(R_{n}\right)$, air temperature $\left(T_{a}\right)$, $5 \mathrm{~cm}$ soil water content $\left(S W C_{5 \mathrm{~cm}}\right)$, vapor pressure deficit $(D)$ as well as the leaf area index ( $L A I)$ were chosen to analyze the effects of the above factors on the $E T$ and its partitioning (E/ET and T/ET). In this study, we referred to the method by [42], where each dependent variable was multiplied by 0.5 and 2.0 in the model, respectively, then the model was rerun to see how much the output value changed (Figure 8 and Table 4). Here, multiplying by 0.5 and 2.0 is defined as "low level" and "high level", respectively, and "standard" is the observed value.

Solar radiation is the most important source of energy for most biological and meteorological processes, and $E T, E$, and $T$ are dependent mainly on the solar energy available to vaporize the water [50]. It was found that $R_{n}$ had little effect on $E T$ partitioning (E/ET and $T / E T$ ) (Figure 8a), but had a great influence on $E T, E$, and $T$ (Table 4), which is consistent with previous research results [50]. ET, E, and T were decreased about $66 \%$ compared with the standard when $R_{n}$ was at a low level and increased about $132 \%$ when $R_{n}$ was doubled (Table 4). The results suggest that the change of $R_{n}$ strongly influences $E T, E$, and $T$, but there was almost no influence on $E / E T$ and $T / E T$ in this degraded meadow ecosystem. 
Table 3. Comparison between $E / E T, T / E T, E T / P$, and vegetation conditions observed in the degraded meadow and values observed in other grassland ecosystems.

\begin{tabular}{|c|c|c|c|c|c|c|c|c|}
\hline Location & Study Period & $E / E T(\%)$ & $T / E T(\%)$ & $E T / P(\%)$ & Vegetation Type & Coverage $(\%)$ & $\begin{array}{l}\text { Maximum } L A I \\
\quad\left(\mathrm{~m}^{2} \cdot \mathrm{m}^{-2}\right)\end{array}$ & References \\
\hline $37^{\circ} 36^{\prime} \mathrm{N}, 101^{\circ} 18^{\prime} \mathrm{E}, 3250 \mathrm{~m}$ a.s.l & 2002-2004 & - & - & $56-61$ & alpine meadow & $>90$ & 3 & [9] \\
\hline $37^{\circ} 37^{\prime} \mathrm{N}, 101^{\circ} 20^{\prime} \mathrm{E}, 3160 \mathrm{~m}$ a.s.l. & 2003-2005 & $40-43$ & $57-60$ & - & alpine meadow & $70-80$ & 4 & [17] \\
\hline $37^{\circ} 40^{\prime} \mathrm{N}, 101^{\circ} 20^{\prime} \mathrm{E}, 3293 \mathrm{~m}$ a.s.l & 2003-2005 & $36-45$ & $55-64$ & - & alpine meadow & $70-80$ & 2.8 & [17] \\
\hline $30^{\circ} 51^{\prime} \mathrm{N}, 91^{\circ} 05^{\prime} \mathrm{E}, 4333 \mathrm{~m}$ a.s.l. & 2004-2005 & $56-60$ & $40-44$ & - & alpine meadow-steppe & $45-55$ & 1.1 & {$[17]$} \\
\hline $43^{\circ} 33^{\prime} \mathrm{N}, 116^{\circ} 40^{\prime} \mathrm{E}, 1252 \mathrm{~m}$ a.s.l. & 2003-2004 & $57-61$ & $39-43$ & - & temperate steppe & $60-70$ & 1.5 & [17] \\
\hline $42^{\circ} 02^{\prime} 48^{\prime \prime} \mathrm{N}, 116^{\circ} 17^{\prime} 01^{\prime \prime} \mathrm{E}, 1350 \mathrm{~m}$ a.s.l & 2005-2006 & - & - & 89 & typical steppe & - & 0.47 & {$[46]$} \\
\hline $43^{\circ} 33^{\prime} 16^{\prime \prime} \mathrm{N}, 116^{\circ} 40^{\prime} 17^{\prime \prime} \mathrm{E}, 1250 \mathrm{~m}$ a.s.l & 2005-2006 & - & - & 107 & degraded steppe & - & 0.25 & [46] \\
\hline $31.9083^{\circ} \mathrm{N}, 110.8395^{\circ} \mathrm{W}, 1000 \mathrm{~m}$ a.s.l & summer 2008 & 63 & 37 & 104 & shrubland & 24 & 0.55 & [7] \\
\hline $31.7438^{\circ} \mathrm{N}, 110.0522^{\circ} \mathrm{W}, 1375 \mathrm{~m}$ a.s.l & summer 2008 & 56 & 44 & 92 & shrubland & 27 & 0.66 & {$[7]$} \\
\hline $43^{\circ} 40^{\prime} 26.61^{\prime \prime} \mathrm{S}, 171^{\circ} 35^{\prime} 27.63^{\prime \prime} \mathrm{E}, 309 \mathrm{~m}$ a.s.l & 2011-2012 & 25 & 75 & 78 & pasture & - & $5-6$ & {$[48]$} \\
\hline $31.737^{\circ} \mathrm{N}, 109.942^{\circ} \mathrm{W}, 1531 \mathrm{~m}$ a.s.l & $2005-2018$ & - & $35-46$ & 91 & grassland & - & $0.56-1.80$ & [49] \\
\hline $34^{\circ} 24^{\prime} \mathrm{N}, 100^{\circ} 24^{\prime} \mathrm{E}, 3963 \mathrm{~m}$ a.s.l & $2006-2008$ & $48-53$ & $47-52$ & $93-95$ & degraded alpine meadow & 55 & 1.20 & $\begin{array}{l}\text { In this } \\
\text { study }\end{array}$ \\
\hline
\end{tabular}

$E / E T$, the ratio of soil evaporation to evapotranspiration; $T / E T$, the ratio of plant transpiration to evapotranspiration; $E T / P$, the ratio of evapotranspiration to precipitation. 

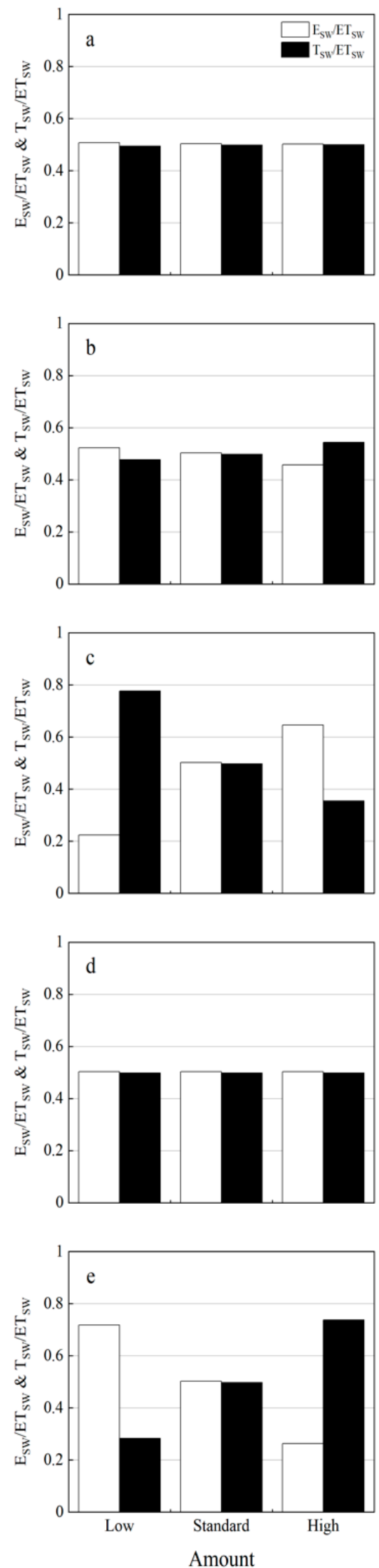

Figure 8. Effects of (a) net radiation, (b) air temperature, (c) $5 \mathrm{~cm}$ soil water content, (d) vapor pressure deficit, and (e) leaf area index on ET partitioning in the growing season of 2007 and 2008 for the degraded meadow. 
Table 4. Effects of net radiation $\left(R_{n}\right)$, air temperature $\left(T_{a}\right), 5 \mathrm{~cm}$ soil water content $\left(S W C_{5 \mathrm{~cm}}\right)$, vapor pressure deficit $(D)$ and leaf area index $(L A I)$ on $E T, E$, and $T$ in the growing season of 2007 and 2008 for the degraded meadow.

\begin{tabular}{ccccccc}
\hline \multirow{2}{*}{ Input Variables } & \multicolumn{5}{c}{ Percentage of Variation } \\
\cline { 2 - 7 } & \multicolumn{3}{c}{$-\mathbf{5 0 \%}$} & \multicolumn{3}{c}{$+\mathbf{1 0 0} \%$} \\
\cline { 2 - 7 } & $\boldsymbol{E T}_{S W}$ & $\boldsymbol{E}_{S W}$ & $\boldsymbol{T}_{S W}$ & $\boldsymbol{E} \boldsymbol{T}_{S W}$ & $\boldsymbol{E}_{S W}$ & $\boldsymbol{T}_{S W}$ \\
\hline Net radiation, $R_{n}\left(\mathrm{MJ} \cdot \mathrm{m}^{-2}\right)$ & $-66 \%$ & $-66 \%$ & $-67 \%$ & $+133 \%$ & $+132 \%$ & $+133 \%$ \\
Air temperature, $T_{a}\left({ }^{\circ} \mathrm{C}\right)$ & $-13 \%$ & $-9 \%$ & $-16 \%$ & $+22 \%$ & $+11 \%$ & $+33 \%$ \\
$5 \mathrm{~cm}$ soil water content, & $-14 \%$ & $-62 \%$ & $+35 \%$ & $+9 \%$ & $+41 \%$ & $-22 \%$ \\
$\quad S W C_{5 \mathrm{~cm}}\left(\mathrm{~m}^{3} \cdot \mathrm{m}^{-3}\right)$ & $-3 \%$ & $+38 \%$ & $-45 \%$ & $+4 \%$ & $-46 \%$ & $+54 \%$ \\
Leaf area index, $L A I\left(\mathrm{~m}^{2} \cdot \mathrm{m}^{-2}\right)$ & $-<1 \%$ & $-<1 \%$ & $-<1 \%$ & $+<1 \%$ & $+<1 \%$ & $+<1 \%$ \\
Vapor pressure deficit, D $(\mathrm{kPa})$ & $-<1 \%$ & & & & \\
\hline
\end{tabular}

Temperature is one of the major factors affecting the rate of $E T, E$, and $T$, and temperature-based models are widely used to estimate $E T$ [51,52]. Our results showed that $E / E T$ was slightly higher (or lower) than the standard when $T_{a}$ was at a low level (or high level), while an opposite change was found for $T / E T$ (Figure $8 b$ ). However, $T_{a}$ had a positive relationship with $E T, E$, and $T$ (Table 4), and the effect of $T_{a}$ on $T$ was greater than $E T$ and $E$ (Table 4). In this study, the variation of $T$ almost followed the same trend of $L A I$ and $T_{a}$ with a higher value in about July (Figures 1,2c and 4), indicating that $T$ increased with the increase in $L A I$ and $T_{a}$, but $E$ decreased rapidly with the increasing $L A I$, therefore the response of $T$ to $T_{a}$ was more sensitive compared with the $E$.

Numerous studies have shown that ecosystem $E T$ is closely related to the soil water content $[10,25,47]$. Our results indicated that $S W C_{5 \mathrm{~cm}}$ affected both $E T$ and its partitioning in this degraded meadow, especially for the $E$ (Figure $8 \mathrm{~d}$, Table 4 ). It was observed that $E / E T$ and $T / E T$ showed the opposite change trend when the $S W C_{5 \mathrm{~cm}}$ was multiplied by 0.5 and 2 (Figure $8 \mathrm{~d}$ ), respectively, in which increasing $S W C_{5 \mathrm{~cm}}$ significantly increased $E / E T$ and decreased $T / E T$, and the converse was also true (Figure $8 \mathrm{~d}$ ). Soil water content is an important factor controlling soil surface resistance, and increasing $S W C_{5 \mathrm{~cm}}$ can reduce bare soil surface resistance to evaporation, and at the same time, increase the supply of soil moisture, resulting in an increase of $E$ and $E / E T$. The previous study pointed out that transpiration will increase rapidly with the increase in soil water content when water supply is limited [53], which is inconsistent with our results. However, transpiration is strongly dependent not only on the soil water content, but also on meteorological and vegetation conditions. In this alpine meadow, most of the root system was distributed within the 0 to $10 \mathrm{~cm}$ surface layer, and the soil maintained a relatively high-water content throughout the growing season due to the abundant precipitation (Figure 2d), while a downward trend of $S W C_{5 \mathrm{~cm}}$ was observed in the peak growing season of July-August due to the high ET. Therefore, under the condition that other observed variables are included in the model, our results showed that $T$ and $T / E T$ decreased when only increasing $S W C_{5 \mathrm{~cm}}$, and the possible reason is that $T$ is predominantly controlled by $R_{n}$ and $L A I$, and at the same time, affected by the $S W C_{5 \mathrm{~cm}}$. The model result is consistent with the actual change in transpiration, and a similar relationship was also observed between the $T$ and $S W C_{5 \mathrm{~cm}}$ in another study by using micro-lysimeter experiments in an alpine meadow of the TRSR (article in print).

Vapor pressure deficit $(D)$ is one of the principal weather variables affecting $E T$ because $D$ affects the evaporation demand of the atmosphere and canopy conductance [9]. Our results showed that $D$ had a very small effect on both $E T$ and its partitioning (Figure 8c, Table 4), perhaps because the value of measured $D$ was very low and varied within a very narrow range from 0.03 to $1.64 \mathrm{kPa}$ in this degraded meadow (Figure 2e), which was significantly lower than many other grassland values with the maximum $D$ ranging from about 2 to $5 \mathrm{kPa}$ [4]. Thus, when $D$ was multiplied by 0.5 and 2.0, there was almost no change in ET as well as its partitioning. 
$L A I$ is one of the important parameters describing vegetation characteristics, which is widely adopted in ET partitioning [6,39]. The simulation results showed that $E / E T$ will increase or decrease significantly compared with the "standard" level when $L A I$ is multiplied by 0.5 or 2.0, while in contrast, an opposite trend was observed for $T$ / ET with increasing or decreasing LAI (Figure 8e) and it was also noted that there was the same trend for $E$ and $T$ (Table 4). Our results are consistent with earlier studies that showed the effects of $L A I$ on $E T$ partitioning $[41,45]$. However, the effect of $L A I$ on $E T$ was relatively small because the $E$ pattern was almost the opposite to that of $T$ during the growing season (Figure 4), so increasing $E$ may be offset by the decreasing $T$. Usually, increasing $L A I$ can increase vegetation cover and lead to a decrease in bare soil surface area, then decreases $E$ and/or increases $T$, and the reverse is also true.

Overall, $L A I$ and $S W C_{5 \mathrm{~cm}}$ are the main important factors influencing $E / E T$ and/or $T / E T$. $E$ and $T$ were primarily controlled by $R_{n}, L A I$, and $S W C_{5 \mathrm{~cm}}$, while the effect of $T_{a}$ on $T$ was relatively large compared with $E$. $D$ had little effect on both $E T$ and $E T$ partitioning.

\subsection{Validation of the Shuttleworth-Wallace Model}

The eddy covariance (EC) system was conducted in our flat degraded meadow. The WPL density correction was applied to water vapor flux [54], and the energy balance ratio $(E B R)$ was calculated using the following equation [55]:

$$
E B R=\frac{\sum(L E+H)}{\sum\left(R_{n}-G\right)}
$$

where $H, L E$, and $G$ are the sensible, latent, and soil heat fluxes. In this study, the term $(L E+H)$, measured by the EC method, seemed to be underestimated since the average value of $E B R$ was 0.79 in the study period, which fell in the median region of reported energy closures, which ranged from 0.55 to 0.99 [55]. LE was converted to $E T$ (mm) by assuming a value for a conversion factor of $2450 \mathrm{~J} / \mathrm{g}$.

In order to verify the performance of the $S-W$ model over the alpine meadow, we compared the $E T$ estimated by the $\mathrm{S}-\mathrm{W}$ model $\left(E T_{S W}\right)$ to that measured by the EC method $\left(E T_{\text {eddy }}\right.$ ) (Figure 9). Overall, there was a good agreement between $E T_{S W}$ and $E T_{\text {eddy }}$ in the study period, while the $E T_{S W}$ was underestimated compared to the $E T_{\text {eddy }}$ from December to April of the next year (Figure 9). Gong et al. [56] also pointed out that the S-W model overestimated and/or underestimated ET at different growth stages in comparison with the results measured by the lysimeter. Therefore, we performed some statistical analyses between $E T_{S W}$ and $E T_{\text {eddy }}$ in the growing and non-growing seasons (Table 5). It was found that the model performance in the growing season was better than that in the non-growing season, and the model overestimation of $E T$ occurred in the growing season, while the underestimation appeared in the non-growing season. The relationships between $E T_{S W}$ and $E T_{\text {eddy }}$ at different growth stages for 2006-2008 were summarized through statistical analyses (Figure 10 and Table 5). The linear regression slopes (k) ranged from 1.04 to 1.06 and the values of $R^{2}$ (square of the correlation coefficient) were over 0.91. RMSE and MAE varied in the range of $0.3-0.6$ and $0.2-0.5 \mathrm{~mm} \cdot \mathrm{d}^{-1}$, respectively. The possible reason for this overestimation of $E T$ might be due to the lack of energy balance closure of the eddy covariance method $(E B R=0.79)$, and thus the $E T$ was underestimated by the EC method. Chen et al. [37] reported that the S-W model overestimated ET by comparing it with the measured data. Wei et al. [57] indicated that the S-W model overestimated ET by $5 \%$ when compared to the measured data, which is similar to our simulation results. On the whole, the ET was well estimated by the S-W model in this degraded meadow on the Qinghai-Tibetan Plateau. 


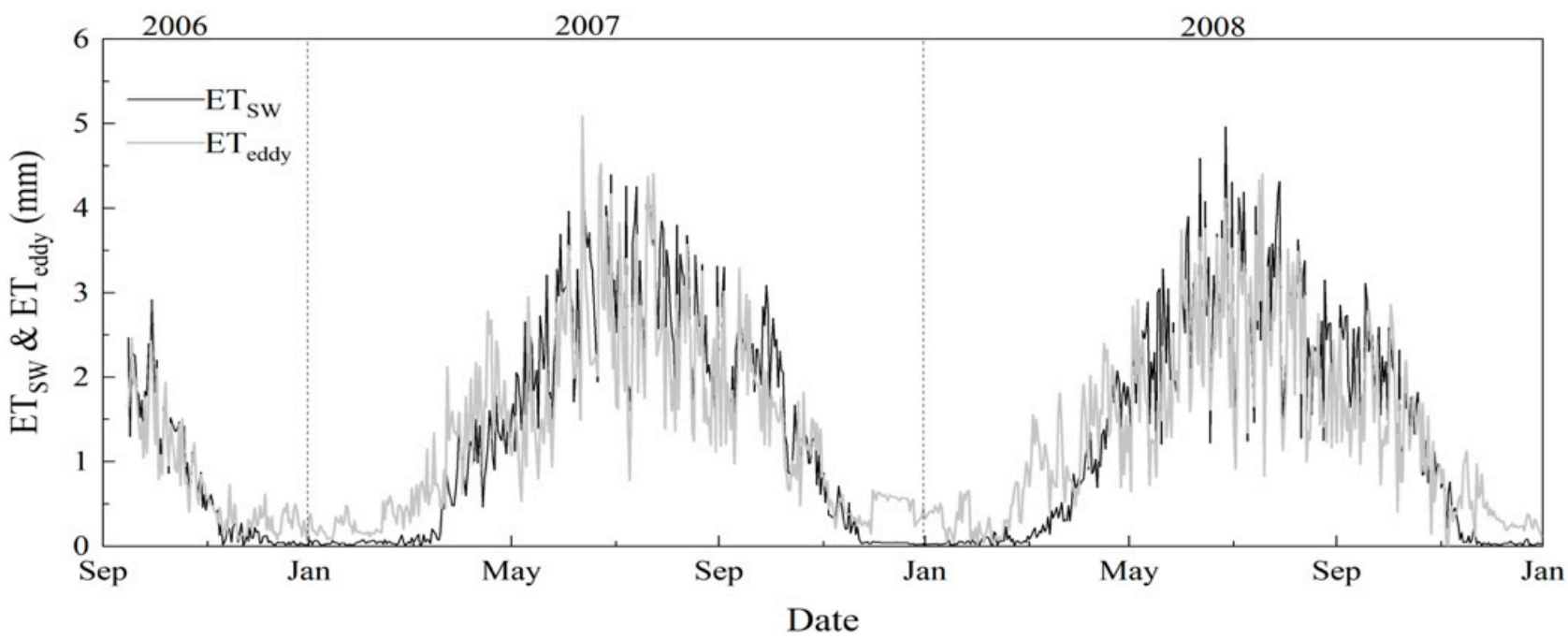

Figure 9. Comparison of the seasonal variations between evapotranspiration estimated by the $\mathrm{S}-\mathrm{W}$ model $\left(E T_{S W}\right)$ and measured by the eddy covariance method $\left(E T_{\text {eddy }}\right)$ for 2006-2008.
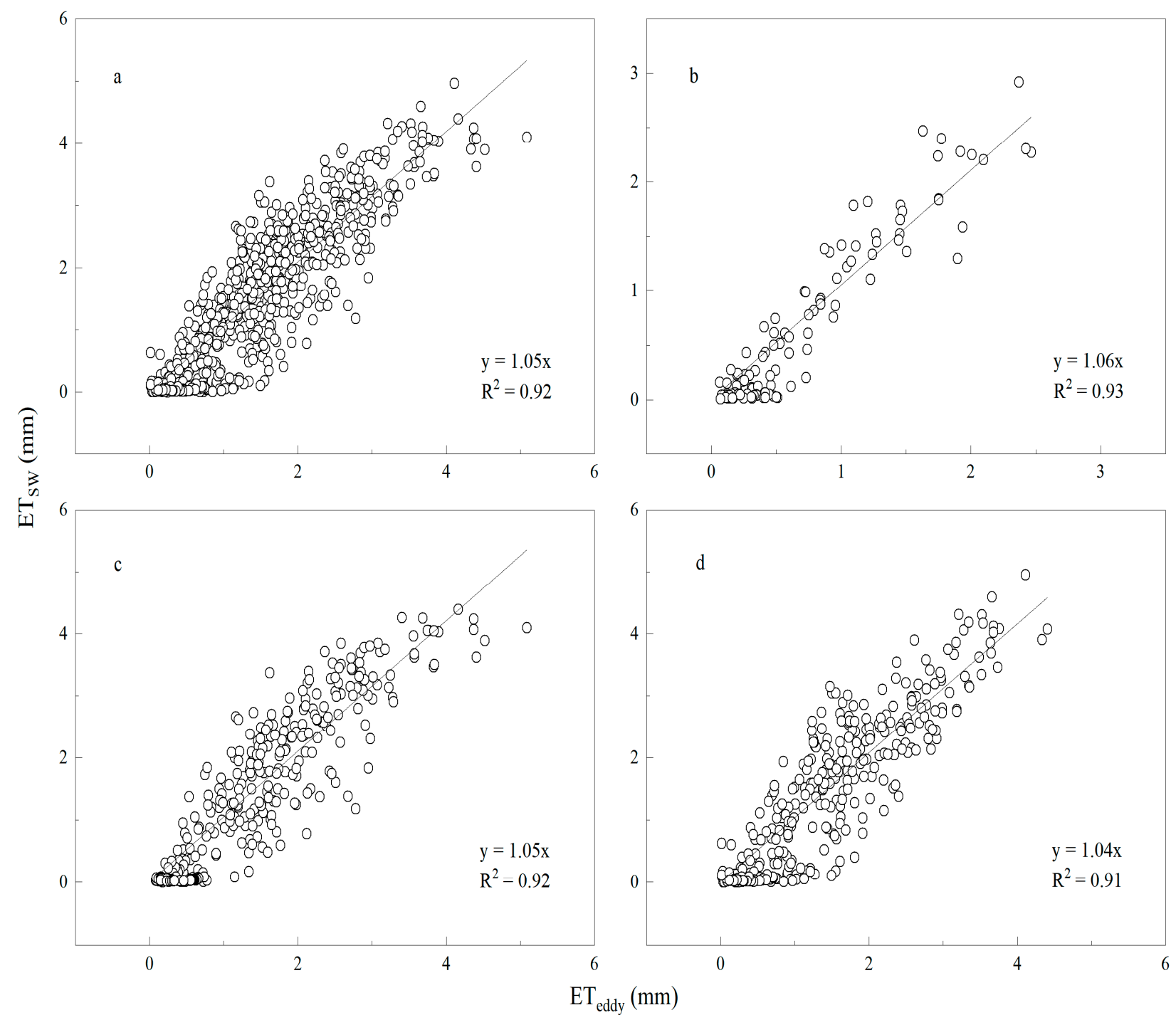

Figure 10. Relationships between evapotranspiration estimated by the $\mathrm{S}-\mathrm{W}$ model $\left(E T_{S W}\right)$ and measured by eddy covariance $\left(E T_{\text {eddy }}\right)$ in the degraded meadow for (a) 2006-2008, (b) 2006, (c) 2007, and (d) 2008, respectively. 
Table 5. Statistical analyses of evapotranspiration estimated by the $\mathrm{S}-\mathrm{W}$ model $\left(E T_{S W}\right)$ and measured by the eddy covariance $\left(E T_{\text {eddy }}\right)$ in the different periods.

\begin{tabular}{cccccc}
\hline Year & Period & $\mathbf{k}$ & $\mathbf{R}^{\mathbf{2}}$ & RMSE & MAE \\
\hline \multirow{2}{2}{2006} & 16 September-31 December & 1.06 & 0.93 & 0.3 & 0.2 \\
\multirow{2}{*}{2007} & Annual & 1.05 & 0.92 & 0.5 & 0.4 \\
& Growing season & 1.13 & 0.96 & 0.6 & 0.5 \\
& Non-growing season & 0.71 & 0.76 & 0.5 & 0.4 \\
2008 & Annual & 1.04 & 0.91 & 0.6 & 0.4 \\
& Growing season & 1.12 & 0.96 & 0.6 & 0.5 \\
& Non-growing season & 0.72 & 0.74 & 0.5 & 0.4 \\
\hline
\end{tabular}

$\mathrm{k}$, slope (dimensionless); $\mathrm{R}^{2}$, determination coefficient; RMSE, root mean square $\left(\mathrm{mm} \cdot \mathrm{d}^{-1}\right)$; MAE, mean absolute error $\left(\mathrm{mm} \cdot \mathrm{d}^{-1}\right)$.

\section{Conclusions}

We estimated evapotranspiration $(E T)$ and its partitioning with the $\mathrm{S}-\mathrm{W}$ model in a degraded alpine meadow in the TRSR, and compared the results with data obtained from eddy covariance. The validation confirmed the good performance of the S-W model for the prediction of $E T$ and its partitioning in this study. Net radiation is the most important factor influencing $E T$ while leaf area index $(L A I)$ is a key factor affecting $E T$ partitioning. Due to the vegetation degradation at our research site, the contribution of soil evaporation (E) accounted for the main part of $E T$, and $E T$ was higher with the lower LAI. Our results suggest that the water lost by ET from the meadow ecosystem increased with the increasing intensity of vegetation degradation, that is, meadow degradation would increase water loss through increasing $E$, leading to reducing the water conservation capacity of the alpine meadow ecosystem in TRSR.

Author Contributions: Conceptualization, S.G. and Y.T.; Methodology, S.G. and L.Z. (Lifeng Zhang); Software, L.Z. (Lifeng Zhang) and Z.C.; Validation, S.G. and L.Z. (Lifeng Zhang); Formal analysis, Z.C. and X.Z.; Investigation, Q.L., D.C. and L.Z. (Liang Zhao); Resources, S.G.; Data curation, L.Z. (Lifeng Zhang) and Z.C.; Writing-original draft preparation, L.Z. (Lifeng Zhang), Z.C., X.Z. and S.G.; Writing-review and editing, L.Z. (Lifeng Zhang), Z.C., X.Z. and S.G.; Visualization, L.Z. (Lifeng Zhang); Supervision, S.G.; Project administration, S.G., Y.T. and L.Z. (Liang Zhao); Funding acquisition, S.G. and Y.T. All authors have read and agreed to the published version of the manuscript.

Funding: This research was funded by the Second Tibetan Plateau Scientific Expedition and Research (STEP) Program (grant number 2019QZKK0106) and the National Natural Science Foundation of China (grant number 31570478).

Data Availability Statement: The data presented in this study are available on request from the corresponding author. The data are not publicly available due to privacy and ethical concerns. All the data used in this study were observed by the authors of the Nankai University and Northwest Institute of Plateau Biology, Chinese Academy of Sciences. The observation equipment was purchased with funds from research projects. Data for this research are not publicly available due to a data confidentiality agreement. Researchers who are related to these projects can obtain these data, and we are not able to provide the original dataset to others at the moment.

Acknowledgments: We thank W.K. Lauenroth, who provided valuable comments on this article.

Conflicts of Interest: The authors declare no conflict of interest. The funders had no role in the design of the study; in the collection, analyses, or interpretation of data; in the writing of the manuscript, or in the decision to publish the results.

\section{References}

1. Garratt, J.R. Sensitivity of Climate Simulations to Land-Surface and Atmospheric Boundary-Layer Treatments-A Review. J. Clim. 1993, 6, 419-448. [CrossRef]

2. Wang, K.; Dickinson, R.E. A review of global terrestrial evapotranspiration: Observation, modeling, climatology, and climatic variability. Rev. Geophys. 2012, 50, RG2005. [CrossRef] 
3. Trenberth, K.E.; Smith, L.; Qian, T.; Dai, A.; Fasullo, J. Estimates of the Global Water Budget and Its Annual Cycle Using Observational and Model Data. J. Hydrometeorol. 2007, 8, 758-769. [CrossRef]

4. Wever, L.A.; Flanagan, L.B.; Carlson, P.J. Seasonal and interannual variation in evapotranspiration, energy balance and surface conductance in a northern temperate grassland. Agric. For. Meteorol. 2002, 112, 31-49. [CrossRef]

5. Williams, D.; Cable, W.; Hultine, K.; Hoedjes, J.; Yepez, E.; Simonneaux, V.; Er-Raki, S.; Boulet, G.; de Bruin, H.; Chehbouni, A.; et al. Evapotranspiration components determined by stable isotope, sap flow and eddy covariance techniques. Agric. For. Meteorol. 2004, 125, 241-258. [CrossRef]

6. Scott, R.L.; Huxman, T.E.; Cable, W.L.; Emmerich, W.E. Partitioning of evapotranspiration and its relation to carbon dioxide exchange in a Chihuahuan Desert shrubland. Hydrol. Process. 2006, 20, 3227-3243. [CrossRef]

7. Cavanaugh, M.L.; Kurc, S.A.; Scott, R. Evapotranspiration partitioning in semiarid shrubland ecosystems: A two-site evaluation of soil moisture control on transpiration. Ecohydrology 2010, 4, 671-681. [CrossRef]

8. Hu, Z.; Li, S.; Yu, G.; Sun, X.; Zhang, L.; Han, S.; Li, Y. Modeling evapotranspiration by combing a two-source model, a leaf stomatal model, and a light-use efficiency model. J. Hydrol. 2013, 501, 186-192. [CrossRef]

9. Gu, S.; Tang, Y.H.; Cui, X.Y.; Du, M.Y.; Zhao, L.; Li, Y.N.; Xu, S.X.; Zhou, H.K.; Kato, T.; Qi, P.T.; et al. Characterizing evapotranspiration over a meadow ecosystem on the Qinghai-Tibetan Plateau. J. Geophys Res. Atmos. 2008, 113, D8. [CrossRef]

10. Giambelluca, T.W.; Scholz, F.G.; Bucci, S.J.; Meinzer, F.; Goldstein, G.; Hoffmann, W.A.; Franco, A.; Buchert, M. Evapotranspiration and energy balance of Brazilian savannas with contrasting tree density. Agric. For. Meteorol. 2009, 149, 1365-1376. [CrossRef]

11. Wang, B.; Jin, H.Y.; Li, Q.; Chen, D.D.; Zhao, L.; Tang, Y.H.; Kato, T.; Gu, S. Diurnal and seasonal variations in the net ecosystem $\mathrm{CO}_{2}$ exchange of a pasture in the three-river source region of the Qinghai-Tibetan Plateau. PLoS ONE 2017, 12, e0170963. [CrossRef]

12. Kool, D.; Agam, N.; Lazarovitch, N.; Heitman, J.L.; Sauer, T.J.; Ben-Gal, A. A review of approaches for evapotranspiration partitioning. Agric. For. Meteorol. 2014, 184, 56-70. [CrossRef]

13. Shuttleworth, W.J.; Wallace, J.S. Evaporation from sparse crops-an energy combination theory. Q. J. R. Meteorol. Soc. 1985, 111, 839-855. [CrossRef]

14. Brisson, N.; Itier, B.; L'Hotel, J.C.; Lorendeau, J.Y. Parameterisation of the Shuttleworth-Wallace model to estimate daily maximum transpiration for use in crop models. Ecol. Model. 1998, 107, 159-169. [CrossRef]

15. Ortega-Farias, S.; Carrasco, M.; Olioso, A.; Acevedo, C.; Poblete-Echeverría, C. Latent heat flux over Cabernet Sauvignon vineyard using the Shuttleworth and Wallace model. Irrig. Sci. 2006, 25, 161-170. [CrossRef]

16. Zhao, P.; Li, S.; Li, F.; Du, T.; Tong, L.; Kang, S. Comparison of dual crop coefficient method and Shuttleworth-Wallace model in evapotranspiration partitioning in a vineyard of northwest China. Agric. Water Manag. 2015, 160, 41-56. [CrossRef]

17. Hu, Z.; Yu, G.; Zhou, Y.; Sun, X.; Li, Y.; Shi, P.; Wang, Y.; Song, X.; Zheng, Z.; Zhang, L.; et al. Partitioning of evapotranspiration and its controls in four grassland ecosystems: Application of a two-source model. Agric. For. Meteorol. 2009, 149, 1410-1420. [CrossRef]

18. Gu, S.; Tang, Y.; Cui, X.; Kato, T.; Du, M.; Li, Y.; Zhao, X. Energy exchange between the atmosphere and a meadow ecosystem on the Qinghai-Tibetan Plateau. Agric. For. Meteorol. 2005, 129, 175-185. [CrossRef]

19. You, Q.; Xue, X.; Peng, F.; Dong, S.; Gao, Y. Surface water and heat exchange comparison between alpine meadow and bare land in a permafrost region of the Tibetan Plateau. Agric. For. Meteorol. 2017, 232, 48-65. [CrossRef]

20. Gu, S.; Tang, Y.H.; Du, M.Y.; Kato, T.; Li, Y.N.; Cui, X.Y.; Zhao, X.Q. Short-term variation of CO2 flux in relation to environmental controls in an alpine meadow on the Qinghai-Tibetan Plateau. J. Geophys Res. Atmos. 2003, 108, D21. [CrossRef]

21. Yao, T.; Thompson, L.G.; Mosbrugger, V.; Zhang, F.; Ma, Y.; Luo, T.; Xu, B.; Yang, X.; Joswiak, D.R.; Wang, W.; et al. Third Pole Environment (TPE). Environ. Dev. 2012, 3, 52-64. [CrossRef]

22. Zhang, G.; Zhang, Y.; Dong, J.; Xiao, X. Green-up dates in the Tibetan Plateau have continuously advanced from 1982 to 2011. Proc. Natl. Acad. Sci. USA 2013, 110, 4309-4314. [CrossRef]

23. Guo, B.; Zhou, Y.; Zhu, J.; Liu, W.; Wang, F.; Wang, L.; Yan, F.; Wang, F.; Yang, G.; Luo, W.; et al. Spatial patterns of ecosystem vulnerability changes during 2001-2011 in the three-river source region of the Qinghai-Tibetan Plateau, China. J. Arid. Land 2015, 8, 23-35. [CrossRef]

24. Qu, B.; Sillanpää, M.; Kang, S.; Yan, F.; Li, Z.; Zhang, H.; Li, C. Export of dissolved carbonaceous and nitrogenous substances in rivers of the "Water Tower of Asia". J. Environ. Sci. 2018, 65, 53-61. [CrossRef] [PubMed]

25. Zhang, X.; Liu, X.Q.; Zhang, L.F.; Chen, Z.G.; Zhao, L.; Li, Q.; Chen, D.D.; Gu, S. Comparison of energy partitioning between artificial pasture and degraded meadow in three-river source region on the Qinghai-Tibetan Plateau: A case study. Agric. For. Meteorol. 2019, 271, 251-263. [CrossRef]

26. Chen, F.; Zhang, J.; Liu, J.; Cao, X.; Hou, J.; Zhu, L.; Xu, X.; Liu, X.; Wang, M.; Wu, D.; et al. Climate change, vegetation history, and landscape responses on the Tibetan Plateau during the Holocene: A comprehensive review. Quat. Sci. Rev. 2020, $243,106444$. [CrossRef]

27. Liu, X.; Zhang, J.; Zhu, X.; Pan, Y.; Liu, Y.; Zhang, D.; Lin, Z. Spatiotemporal changes in vegetation coverage and its driving factors in the Three-River Headwaters Region during 2000-2011. J. Geogr. Sci. 2014, 24, 288-302. [CrossRef]

28. Liu, J.; Xu, X.; Shao, Q. Grassland degradation in the "three-river headwaters" region, Qinghai province. J. Geogr. Sci. 2008, 18, 259-273. [CrossRef] 
29. Feng, J.; Wang, T.; Qi, S.; Xie, C. Land degradation in the source region of the Yellow River, northeast Qinghai-Xizang Plateau: Classification and evaluation. Environ. Earth Sci. 2004, 47, 459-466. [CrossRef]

30. Zhang, Y.; Zhang, S.; Zhai, X.; Xia, J. Runoff variation and its response to climate change in the Three Rivers Source Region. J. Geogr. Sci. 2012, 22, 781-794. [CrossRef]

31. Li, H.; Liu, G.; Fu, B. Estimation of regional evapotranspiration in alpine area and its response to land use change: A case study in Three-River Headwaters region of Qinghai-Tibet Plateau, China. Chin. Geogr. Sci. 2012, 22, 437-449. [CrossRef]

32. Zhang, Y.; Zhang, S.; Xia, J.; Hua, D. Temporal and spatial variation of the main water balance components in the three rivers source region, China from 1960 to 2000. Environ. Earth Sci. 2012, 68, 973-983. [CrossRef]

33. Zeng, C.; Zhang, F.; Wang, Q.; Chen, Y.; Joswiak, D.R. Impact of alpine meadow degradation on soil hydraulic properties over the Qinghai-Tibetan Plateau. J. Hydrol. 2013, 478, 148-156. [CrossRef]

34. Falge, E.; Baldocchi, D.; Olson, R.; Anthoni, P.; Aubinet, M.; Bernhofer, C.; Burba, G.; Ceulemans, R.J.; Clement, R.; Dolman, A.; et al. Gap filling strategies for defensible annual sums of net ecosystem exchange. Agric. For. Meteorol. 2001, 107, 43-69. [CrossRef]

35. Zhou, M.C.; Ishidaira, H.; Hapuarachchi, H.P.; Magome, J.; Kiem, A.S.; Takeuchi, K. Estimating potential evapotranspiration using Shuttleworth-Wallace model and NOAA-AVHRR NDVI data to feed a distributed hydrological model over the Mekong River basin. J. Hydrol. 2006, 327, 151-173. [CrossRef]

36. Farahani, H.J.; Bausch, W.C. Performance of Evapotranspiration Models for Maize-Bare Soil to Closed Canopy. Trans. ASAE 1995, 38, 1049-1059. [CrossRef]

37. Chen, H.; Huang, J.J.; McBean, E. Partitioning of daily evapotranspiration using a modified shuttleworth-wallace model, random Forest and support vector regression, for a cabbage farmland. Agric. Water Manag. 2020, 228, 105923. [CrossRef]

38. García-Leoz, V.; Villegas, J.C.; Suescún, D.; Flórez, C.P.; Merino-Martín, L.; Betancur, T.; León, J.D. Land cover effects on water balance partitioning in the Colombian Andes: Improved water availability in early stages of natural vegetation recovery. Reg. Environ. Chang. 2018, 18, 1117-1129. [CrossRef]

39. Hu, H.; Chen, L.; Liu, H.; Khan, M.Y.A.; Tie, Q.; Zhang, X.; Tian, F. Comparison of the Vegetation Effect on ET Partitioning Based on Eddy Covariance Method at Five Different Sites of Northern China. Remote Sens. 2018, 10, 1755. [CrossRef]

40. Li, S.-G.; Lai, C.-T.; Lee, G.; Shimoda, S.; Yokoyama, T.; Higuchi, A.; Oikawa, T. Evapotranspiration from a wet temperate grassland and its sensitivity to microenvironmental variables. Hydrol. Process. 2004, 19, 517-532. [CrossRef]

41. Marques, T.V.; Mendes, K.; Mutti, P.; Medeiros, S.; Silva, L.; Perez-Marin, A.M.; Campos, S.; Lúcio, P.S.; Lima, K.; dos Reis, J.S.; et al. Environmental and biophysical controls of evapotranspiration from Seasonally Dry Tropical Forests (Caatinga) in the Brazilian Semiarid. Agric. For. Meteorol. 2020, 287, 107957. [CrossRef]

42. Lauenroth, W.K.; Bradford, J. Ecohydrology and the Partitioning AET between Transpiration and Evaporation in a Semiarid Steppe. Ecosystems 2006, 9, 756-767. [CrossRef]

43. Zhu, G.; Su, Y.; Li, X.; Zhang, K.; Li, C. Estimating actual evapotranspiration from an alpine grassland on Qinghai-Tibetan plateau using a two-source model and parameter uncertainty analysis by Bayesian approach. J. Hydrol. 2013, 476, 42-51. [CrossRef]

44. Li, S.G.; Eugster, W.; Asanuma, J.; Kotani, A.; Davaa, G.; Oyunbaatar, D.; Sugita, M. Energy partitioning and its biophysical controls above a grazing steppe in central Mongolia. Agric. For. Meteorol. 2006, 137, 89-106. [CrossRef]

45. Wei, Z.; Yoshimura, K.; Wang, L.; Miralles, D.G.; Jasechko, S.; Lee, X. Revisiting the contribution of transpiration to global terrestrial evapotranspiration. Geophys. Res. Lett. 2017, 44, 2792-2801. [CrossRef]

46. Chen, S.; Chen, J.; Lin, G.; Zhang, W.; Miao, H.; Wei, L.; Huang, J.; Han, X. Energy balance and partition in Inner Mongolia steppe ecosystems with different land use types. Agric. For. Meteorol. 2009, 149, 1800-1809. [CrossRef]

47. Liu, H.Z.; Feng, J.W. Seasonal and interannual variations of evapotranspiration and energy exchange over different land surfaces in a semiarid area of China. J. Appl. Meteorol. Climatol. 2012, 51, 1875-1888.

48. Graham, S.; Kochendorfer, J.; McMillan, A.; Duncan, M.J.; Srinivasan, M.; Hertzog, G. Effects of agricultural management on measurements, prediction, and partitioning of evapotranspiration in irrigated grasslands. Agric. Water Manag. 2016, 177, 340-347. [CrossRef]

49. Scott, R.L.; Knowles, J.F.; Nelson, J.A.; Gentine, P.; Li, X.; Barron-Gafford, G.; Bryant, R.; Biederman, J.A. Water availability impacts on evapotranspiration partitioning. Agric. For. Meteorol. 2021, 297, 108251. [CrossRef]

50. Pereira, A.B.; Nova, N.A.V.; Pires, L.F.; Angelocci, L.R.; Beruski, G.C. Estimation method of grass net radiation on the determination of potential evapotranspiration. Meteorol. Appl. 2012, 21, 369-375. [CrossRef]

51. Yang, L.; Feng, Q.; Adamowski, J.F.; Yin, Z.; Wen, X.; Wu, M.; Jia, B.; Hao, Q. Spatio-temporal variation of reference evapotranspiration in northwest China based on CORDEX-EA. Atmos. Res. 2020, 238, 104868. [CrossRef]

52. Rosenberg, N.J.; Blad, B.L.; Verma, S.B. Evaporation and Evapotranspiration, in Microclimate: The Biological Environment, 2nd ed.; Wiley-Intersci.: New York, NY, USA, 1983; pp. 209-287.

53. Novák, V.; Hurtalova, T.; Matejka, F. Predicting the effects of soil water content and soil water potential on transpiration of maize. Agric. Water Manag. 2005, 76, 211-223. [CrossRef]

54. Webb, E.K.; Pearman, G.I.; Leuning, R. Correction of flux measurements for density effects due to heat and water vapour transfer. Q. J. R. Meteorol. Soc. 1980, 106, 85-100. [CrossRef]

55. Wilson, K.; Goldstein, A.; Falge, E.; Aubinet, M.; Baldocchi, D.; Berbigier, P.; Bernhofer, C.; Ceulemans, R.J.; Dolman, A.; Field, C.; et al. Energy balance closure at FLUXNET sites. Agric. For. Meteorol. 2002, 113, 223-243. [CrossRef] 
56. Gong, X.; Liu, H.; Sun, J.; Gao, Y.; Zhang, H. Comparison of Shuttleworth-Wallace model and dual crop coefficient method for estimating evapotranspiration of tomato cultivated in a solar greenhouse. Agric. Water Manag. 2019, 217, 141-153. [CrossRef]

57. Wei, G.; Zhang, X.; Ye, M.; Yue, N.; Kan, F. Bayesian performance evaluation of evapotranspiration models based on eddy covariance systems in an arid region. Hydrol. Earth Syst. Sci. 2019, 23, 2877-2895. [CrossRef] 